\title{
Factors Associated with the Risk of Autism in Children Under Five Years of Age: A Path Analysis Evidence from Banten
}

\author{
Fitriyani Dwi Astuti'), Harsono Salimo²), Eti Poncorini Pamungkasari3) \\ 1)Masters Program in Public Health, Universitas Sebelas Maret \\ 2) Department of Pediatrics, Dr. Moewardi Hospital, Surakarta \\ 3)Department of Public Health, Faculty of Medicine, Universitas Sebelas Maret
}

\begin{abstract}
Background: Autism, now increasingly referred to as autism spectrum disorder (ASD) is a set of clinical phenotypes mirroring an early-onset neurodevelopmental disorder affecting social communication, imagination, and behavior. Children with ASD develop differently from other children. They also have challenges in interacting and communicating with others. These challenges can affect their development and learning. This study aimed to determine factors associated with the risk of autism in children under five.

Subjects and Method: This was a case control study carried out at two special schools for children with development problem in Tangerang, Banten, from February to March 2018. A sample of 200 children aged 1-5 years was selected by fixed disease sampling, consisting of 50 children with autism and 150 normal children. The dependent variable was autism. The independent variables were family income, maternal education, maternal age, gestational stress, chemical exposure, nutritional intake, fever at pregnancy, growth and development impairment, and mumps-measles-rubella (MMR) vaccine. Data on immunization status, growth and development were taken from medical record. Data on the other variables were collected by questionnaire.The data were analyzed by path analysis.

Results: The risk of autism increased with chemical exposure $(b=2.86 ; 95 \% C I=0.77$ to $4.96 ; p=$ 0.007), gestational stress $(b=2.45 ; 95 \% \mathrm{CI}=0.60$ to $4.30 ; \mathrm{p}=0.010)$, growth and development impairment $(\mathrm{b}=1.69 ; 95 \% \mathrm{CI}=-0.24$ to $3.61 ; \mathrm{p}=0.086)$, and maternal age $\geq 35$ years $(\mathrm{b}=2.82 ; 95 \%$ $\mathrm{CI}=0.73$ to $4.92 ; \mathrm{p}=0.008)$. Autism decreased with good nutritional intake $(\mathrm{b}=-2.08 ; 95 \% \mathrm{CI}=-$ 3.88 to $-0.28 ; \mathrm{p}=0.023$ ). The risk of autism was indirectly affected by fever at pregnancy, chemical exposure, family income, and maternal education. MMR vaccine did not affect the incidence of autism ( $b=1.12 ; 95 \% \mathrm{CI}=-2.11$ to $4.36 ; \mathrm{p}=0.500)$.

Conclusion: The risk of autism increases with chemical exposure, gestational stress, growth and development impairment, maternal age $\geq 35$ years, and decreases with good nutritional intake. MMR vaccine does not affect the incidence of autism in children.
\end{abstract}

Keywords: autism, chemical exposure, growth and development impairment, MMR vaccine, children under five

\section{Correspondence:}

Fitriyani Dwi Astuti. Masters Program in Public Health, Universitas Sebelas Maret, Jl. Ir. Sutami 36A, Surakarta 57126, Central Java. Email: fitriyani.dwi.astuti@gmail.com.

Mobile: +6281316730755 .

\section{BACKGROUND}

Autism is one of problems that still occur globally though the trend for autism itself tends to fall. The prevalence of autism globally according to data obtained from UNESCO is approximately 35 million people with autism which means that there are 6 out of 1000 people having autism (Desinta et al., 2015). Autism is a syndrome of complex brain damage that causes communication, behavioral, emotional, and social interactions in which these symptoms can be seen before the age of 3 years. The characteristics of not listening or 
looking at the eye when communicating, has unusual behavior, communication that is difficult to understand and has also unstable emotions. Generally, individuals with autism often do strange movements and recite words that are difficult to understand (Helland et al., 2017; Posserud et al., 2016; Baio, 2014).

The prevalence of autism in Indonesia based on data owned by the Central Bureau of Statistics consists of $1,500,000$ Indonesian children who have autism (Manalu et al., 2013). Preliminary surveys that have been done in the Autism House have approximately 200 children with autism with different age variations. According to Hoogsteen and Woodgate (2015), economic factors are the source of the problem of lack of nutrition because the ability of a family to meet food needs depends on the income earned by the family. Inadequate family income and less family nutrient fulfillment are likely to affect the incidence of autism (Sudarsih and Wijayanti, 2013).

Maternal education, growth disorders, and age at pregnancy above 40 also have an effect on autism (Ahmadi, 2014; Hardinsyah and Supariasa, 2016; Lee and Mc Grath, 2015). Maternal stress during pregnancy is a factor in the occurrence of autism (Seymour, 201; Ahmed et al., 2017; Schetter and Tanner, 2012) due to fetal developmental disorders especially in fetal brain development (Pangestu and Febriana, 2017). Biopsychosocial models are models used to explain biological, psychological and social factors. Determinants of disease determinants based on biological causesare not sufficient to explain the occurrence of disease processes in the body (Murti, 2016).

Based on this background and the high number of infants with autism in Tangerang City, the author are interested to examine further, especially in analyzing biopsyosocial and environmental factors associated with the incidence of autism in toddlers in Tangerang, Indonesia.

\begin{tabular}{l}
\hline SUBJECTS AND METHOD \\
\hline 1. Study Design \\
This was an analytic observational study \\
with a case control design. The study was \\
conducted at Special School Children with \\
special needs and autism house in Jati- \\
uwung and Karawaci sub-districts. The \\
study was conducted from February to \\
March 2018.
\end{tabular}

\section{Population and Samples}

The source population in this study were children aged 1-5 years who experienced autism and a normal age of 1-5 years in Tangerang. A sample of 200 children under five was selected by fixed disease sampling, consisting of 50 autism children and 150 normal children.

\section{Study Variables}

The dependent variable was autism. The independent variables were family income, maternal education, parental age, maternal stress, chemical exposure, family nutritional status, maternal gestational fever, and growth disorders.

\section{Operational Definition of Variables}

Autism was defined as a syndrome caused by a complex brain damage that causes communication, emotional, behavioral, and social interactions, which can be seen before the age of 3 years. The data were taken from The Modified Checklist for Autism in Toddlers (M-CHAT questionnaire).

Child development impairment was defined as obstruction of interaction, communication, and behavior among autism children. Behavioral disorders in children with autism are seen from the inability of children to connect with other people as if they live in their own world. In general, children with autism often make strange movements and recite words that are 
difficult to understand the children their age. Child development was measured by questionnaire. The measurement scale was continuous.

Family income during pregnancy was defined as a family income (husband and wife) received in the form of money from the work that includes not only basic salary but also including overtime and benefits received regularly during pregnancy. The data was measured by questionnaire. The measurement scale was continuous.

Maternal education was defined as maternal last formal education level that is taken up to get a diploma. The data was measured by questionnaire. The measurement scale was categorical.

Stress during pregnancy was defined as a condition that forces and burdens pregnant women that cause tension which can be in the form of spouse or family support, environmental conditions of residence and culture that interfere with the psychological state of the mother during pregnancy. The data was measured by questionnaire. The measurement scale was continuous.

Chemical exposure was defined as drugs contamination that affects fetal growth during pregnancy which has a greater risk of autism. The data was measured by questionnaire. The measurement scale was continuous.

Maternal age was defined as age of the mother from the time of birth until the day of data collection. The data was measured by questionnaire. The measurement scale was continuous.

Family nutrition status was defined as a nutrient needed by mother during pregnancy based on nutrients consumed by mother to fulfill balanced nutrition for herself and for growth and development of fetus. The data was measured by questionnaire. The measurement scale was continuous.

Fever during pregnancy was defined as a condition or body disorder in the form of flu or fever that prolonged during pregnancy. The data was measured by questionnaire. The measurement scale was categorical.

MMR immunization was defined as an immunization that aims to provide immunity while preventing measlesmumps-rubella. The data were taken from mother and child health monitoring book.

\section{Data Analysis}

The data analysis was conducted using path analysis with Stata 13 program to know the direct or indirect influence of determinant. The path analysis steps in this research are model specification, model identification, suitability model, parameter estimation and respesification model.

\section{Research Ethics}

The research ethics include informed consent, anonymity, confidentiality and ethical clearance. The ethical clearance in this study was conducted in Dr. Moewardi hospital, Surakarta, Central Java.

\section{RESULTS}

\section{Characteristics of study subjects}

The study subject characteristics were described on Table 1. Most of the study subjects had high family income (64.5\%), low maternal education (65\%), low maternal stress $(65 \%)$, good family nutritional status (74\%), never had fever during pregnancy (82\%), and low chemical exposure (57.5\%). Most of the children ever had MMR vaccine (91\%). 
Table1. Study subjects characteristics

\section{Characteristics of subjects}

\section{Family Income during pregnancy} Frequency (n) $\quad$ Percentage (\%)

$<$ Minimum wage (code 0 )

$\geq$ Minimum wage (code 1 )

$35 \cdot 5$

71

129

64.5

Maternal education

- Low ( code 0 )

$96 \quad 48$

- High (code 1)

104

52

Parental Age

- 25 - 34 years old (code o)

- 35 - 45 years old (code 1 )

110

55

90

45

Maternal stress during pregnancy

- Low (code o)

- High (code 1)

130

65

70

35

Chemical Exposure

- Not exposed (code o)

115

42.5

- Exposed (code 1)

Family nutrition during pregnancy

- Poor (code o)

- Good (code 1)

$$
85
$$

26

52

148

74

Fever during pregnancy

- Not fever (code 0)

- Fever (code 1)

164

36

82

Growth disorder

- Not disturbed (code o)

- Disturbed (kode 1)

100

100

18

MMR vaccine

- No MMR vaccine(code o)

- MMR vaccine (code 1 )
18

182

\section{8}

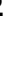


Journal of Maternal and Child Health (2018), 3(4): 278-286

https://doi.org/10.26911/thejmch.2018.03.04.05

Table 2. The results of path analysis of biopsychosocial and environmental factors associated with autism

\begin{tabular}{|c|c|c|c|c|c|c|}
\hline \multirow[b]{2}{*}{ Dependent Variable } & \multirow{2}{*}{\multicolumn{2}{|c|}{$\begin{array}{l}\text { Independent } \\
\text { variables }\end{array}$}} & \multirow[b]{2}{*}{$\mathbf{b}$} & \multicolumn{2}{|c|}{ 95\% CI } & \multirow[b]{2}{*}{$\mathbf{p}$} \\
\hline & & & & $\begin{array}{c}\text { Lower } \\
\text { Limit }\end{array}$ & $\begin{array}{l}\text { Upper } \\
\text { Limit }\end{array}$ & \\
\hline \multicolumn{7}{|l|}{ Direct Effect } \\
\hline Autism & $\leftarrow$ & Chemical exposure & 2.86 & 0.77 & 4.96 & 0.007 \\
\hline Autism & $\leftarrow$ & High stress & 2.45 & 0.60 & $4 \cdot 30$ & 0.010 \\
\hline Autism & $\leftarrow$ & Growth impairment & 1.69 & -0.24 & 3.61 & 0.086 \\
\hline Autism & $\leftarrow$ & MMR Vaccine & 1.12 & -2.11 & $4 \cdot 36$ & 0.500 \\
\hline Autism & $\leftarrow$ & Good nutritional status & -2.08 & -3.88 & -0.28 & 0.023 \\
\hline Autism & $\leftarrow$ & Fever during pregnancy & 3.10 & 1.11 & 5.08 & 0.002 \\
\hline Autism & $\leftarrow$ & Maternal age & 2.82 & 0.73 & 4.92 & 0.008 \\
\hline \multicolumn{7}{|l|}{ Indirect Effect } \\
\hline Growth impairment & $\leftarrow$ & Chemical exposure & 0.52 & -0.05 & 1.10 & 0.074 \\
\hline Growth impairment & $\leftarrow$ & Fever during pregnancy & 0.67 & -0.08 & 1.42 & 0.079 \\
\hline Fever during pregnancy & $\leftarrow$ & MMR vaccine & 1.16 & 0.47 & 1.86 & 0.001 \\
\hline Fever during pregnancy & $\leftarrow$ & High family income & -0.74 & -1.47 & -0.01 & 0.048 \\
\hline Family income & $\leftarrow$ & High education & 0.61 & 0.02 & 1.20 & 0.042 \\
\hline \multicolumn{7}{|l|}{$\mathrm{N}$ observation $=200$} \\
\hline Log Likelihood = -377.01 & & & & & & \\
\hline
\end{tabular}

\section{The results of path analysis}

Path analysis model of this study was depicted in Figure 1. The result of path analysis was described Table 2.

The risk of autism in children was directly and positively affected by chemical exposure, high stress, growth impairment, MMR vaccine, fever, and maternal age, but decreased with good nutritional status.

The risk of autism increased with high chemical exposure during pregnancy $(b=$ 2.86; $95 \% \mathrm{CI}=0.77$ to $4.96 ; \mathrm{p}=0.007)$, high maternal stress during pregnancy $(b=2.45$; 95\% $\mathrm{CI}=0.60$ to $4.30 ; \mathrm{p}=0.010$ ), growth and development impairment $(b=1.69$; $95 \% \mathrm{CI}=-0.24$ to $3.61 ; \mathrm{p}=0.086)$, maternal age $\geq 35$ years old $(b=2.82 ; 95 \% \mathrm{CI}=0.73$ - 4.92; $\mathrm{p}=0.008)$, and MMR vaccine $(\mathrm{b}=$ $1.12 ; 95 \% \mathrm{CI}=-2.11$ to $4.36 ; \mathrm{p}=0.500$ ).

The risk of autism decreased with good family nutrition $(b=-2.08 ; 95 \% \mathrm{CI}=$ 3.88 to $-0.28 ; \mathrm{p}=0.023)$.

The risk of autism in children was indirectly affected by maternal education and family income.

\section{DISCUSSIONS}

1. The effect of chemical exposure at pregnancy on autism

The result of the study showed that there was a direct and positive association between chemical exposure at pregnancy and autism.

The growth of the fetus in the womb was very rapid, therefore, the fetus must be properly guarded to avoid the growth and development disorders. Teratogenic substances can lead to physical and mental abnormalities, including TORCH infections and chemicals. This substance was not only caused congenital abnormalities but also affected the cognitive developmental disorder (Soetjiningsih,2013).

Exposure to pesticides was associated with the incidence of autism. Some studies have found that pesticides might impair gene function in the central of nervous system.Based on the statements of Dr. Alice Mao, a professor of psychiatry, chemicals in pesticides has an impact on those with autism(Fujiwara et al., 2016). 


\section{The effect of stress at pregnancy on autism}

The result of the study showed that maternal stress at pregnancy was directly and positively affected autism. Psychological changes in pregnant women such as stress would give a bad impression for mothers and fetuses if it was not treated properly (Ahmed et al., 2017). Pregnant women who have stress, anxiety, and depression were at risk of giving birth to babies in early pregnancy, and caused growth and development impairment of the fetus (Schetter and Tanner, 2012).

A study by Pangestu and Febriana (2017) showed that pregnant women who have high levels of stress were 4.1 times more likely to give birth to autistic infants than pregnant women who have low stress levels. Pregnant women with stress was a sign that the mother experiencing unhappiness in the process of pregnancy that increased the adrenaline hormone in their body then resulted in a narrowing of blood vessels in the placenta that affected the blood flow in the fetal brain which lead to impaired development of the fetus, especially in fetal brain development.

\section{The effect of growth and develop- ment impairment on autism.}

The result of the study showed that there was a direct and significant effect between growth and development impairment exposure and autism.

Impaired growth and development could affect the incidence of autism. Disorder that occur were mainly in interaction, communication, and behavior. Behavioral disorders in children with autism can be seen from the inability of children to interact with other people like they were living in their own world. Generally, children with autism often made strange movements and said words repeatedly which were difficult to understand by their peer (Baio, 2014).

Maternal education during pregnancy could affect the autism through children growth and development, therefore, it can be one of the factors that caused growth and development disorders, based on the results of the study, it showed that the case of children with autism and have development disorders was related to low maternal education during pregnancy. Pregnant women with low education were susceptible to suffering from malnutrition and have risk of delivering babies with low birth weight that have an impact on the children's growth and development, productivity, and also their intellectual in the future which might have an impact on the incidence of autism (Hardinsyah and Supariasa, 2016).

\section{The effect of MMR immunization on autism.}

The result of the study showed that there was an indirect and insignificant effect between MMR immunizatin and autism.

The result was in line with the WHO agreement stating that there was no relationship between MMR vaccine and the incidence of autism. However, the WHO warned that MMR vaccine was probably can caused autism in some children. Central for disease control and prevention (CDC) also did not explain about the association between MMR vaccine and autism. MMR vaccine safety and research has been done to prove the findings, so that the MMR vaccine was still a recommendation that should be given to children. In addition, POM IDA agency also explained the same thing that there was no association between the MMR vaccine with the incidence of autism and further evaluation would be done to assess the safety and effectiveness of MMR vaccine. This was in line withPangestu and Febriana (2017) who 
stated that in addition to factors from the environment, autism can be caused by genetic factors.

\section{The effect of family nutritional status on autism}

The result of the study showed that there was a direct and positive effect between good family nutritional status and autism. Pregnant women with poor nutrition intake both in quality and quantity affected on the lack of maternal weight gain, and impaired growth and development of the fetus (Harti et al., 2016).

Pregnant women who experienced malnutrition in the first trimester would usually have premature babies, fetal mortality, and abnormalities in the central nervous system of the baby. Lack of nutrient and energy intake in the second and third trimesters of pregnancy would inhibit the growth of the fetus or the fetus can not develop according to gestational age (Hardinsyah and Supariasa, 2016).

Pregnant mothers need higher nutrition intake than non pregnant mother. Nutrition intake was associated with maternal health and infant growth. Pregnant women should to fulfill the balanced nutrition by consuming a variety of food in order to prevent child growth and development impairment that would lead to the incidence of autism (Hardinsyah and Supariasa, 2016).

\section{The effect of fever at pregnancy on autism}

The result of the study showed that there was a direct and significant effect between fever at pregnancy and autism. Chidlren with autism were increasing over time. Pregnant women with flu or prolonged fevers were more likely to give birth to autistic children, mild fevers and urinary tract infections were not the main factors which causedautism in children (Taylor et al., 2014). Zerbo et al., (2013) explained that toddlers from influenza-infected mothers were two times more likely to have autism at three years old, while pregnant women with fever for 1 week or more were three times more likely to give birth to autistic children. Pregnant women could avoid it by doing influenza immunization every six months even though they did not have flu or fever, influenza immunization was highly important as the prevention of the incidence of autism in children.

\section{The effect of age at pregnancy on autism.}

The result of the study showed that there was a direct and significant effect between age at pregnancy and autism.

Maternal age at pregnancy was one of the risk factors of autism. A study conducted in California, USA in 2010 stated that maternal age over 40 years old were 1.51 times more likely in contributing to the risk of autism compared to pregnant women aged 25-29 years old, and have 1.77 times greater risk of causing autism compared to pregnant women who were less than 25 years old (Jumai'an et al., 2011; Parner et al., 2012).

Lee and McGrath (2015) also explained that women who were pregnant at the age of 40 years old have $50 \%$ risk of having children with autism compared to pregnant women who were 20-29 years old.

Based on the results of this study, it can be concluded that the risk of autism is related to maternal age $\geq 35$ years old, high maternal stress, chemical exposure, fever at pregnancy, and growth and development impairment. The risk of autism is decreased in infants with high family income and high maternal education.

\section{REFERENCE}

Ahmadi R. (2014). Pengantar Pendidikan. Yogyakarta: Ar-ruzz media. 
Ahmed MN, Fadel AE, Khedr HFN (2017). Stressors And Social Support Among Pregnant Women. Journal Of Nursing And Health Science, 6 (4): 52-58.

Baio J (2013). Autism Spectrum Disorders (ASDs) Homepage data and Statistics. 27-07-2013. http//www.cdc.gov/ncbddd/autism/data.html.

Deshinta R, Hardiani SR, Dewi IE (2015). Pengaruh Metode Glenn Doman terhadap Kemampuan Interaksi Sosial Anak Autis di SLB-B dan Autis TPA (Taman Pendidikan dan Asuhan) Kabupaten Jember. e-Jurnal Pustaka Kesehatan, 3 (1).

Fujiwara T, Morisaki N, Honda Y, Sampei M, Tani Y (2016). Chemicals, nutrition, and autism spectrum disorder: A mini-review. Frontiers in Neuroscience. doi:10.3389/fnins.2016.00174.

Hardinsyah \& Supariasa. (2016). Buku ilmu gizi: Teori dan Aplikasi, Jakarta: Penerbit buku kedokteran EGC.

Harti BL, Kusumastuty I, Hariadi I. (2016). Hubungan Status Gizi dan Pola Makan Terhadap Penambahan Berat Badan Ibu Hamil. Indonesian Journal Of Human Nutrition, 3 (1): 54-62.

Helland WA, Helland T (2017). Emotional and Behavioural Needs in Children with Specific Language Impairment and in Children with Autism Spectrum Disorder: the Importance of Pragmatic Language Impairment. Research in Developmental Disabilities, 70: 33 - 39. http://dx.doi.org/10.1016/j.ridd.2017.08.009.

Hoogsteen L, Woodgate RL (2013). Centering Autism Within the Family: A Qualitative Approach to Autism and the Family. Journal of Pediatric Nursing, 28: 135-140. doi:10.1016/j.pedn.2012.06.002.

Jumai'an AA, Dmour HH, Al Soud HM. (2011). No Relation Between Advan- ced Parental Age and The Risk of Autism Among Jordanian Children. Journal of the royal Medical Services, $18: 27-32$.

Lee BK, McGrath JJ (2015). Advancing Parental Age and Autism: Multifactorial Pathways. Trends in Molecular Medicine. doi:10.1016/j.molmed.2014.11.005.

Manalu PA, Ramayanti I, Arsyad KHM (2013). Laporan Kasus: Faktor-Faktor Kejadian Penyakit Autisme Anak di Bina Autis Mandiri Palembang, Syifa Medika, 4 (1).

Murti B. (2013). Buku Desain dan Ukuran Sampel untuk Penelitian Kuantitatif dan Kualitatif di Bidang Kesehatan. Yogyakarta: Gadjah Mada University Press.

Pangestu N, Fibriana IN (2017). Faktor Risiko Kejadian Autis, HIGEIA. journal of Public Health Research and Development, 1(2).

Parner ET, Baron CS, lauritsen MB, Jorgensen M, Schieve LA, Yeagin Allsop M (2012). Parental Age and autism Spectrum Disorder. Elsevier, 1-8.

Posserud M, Hysing M, Helland W (2016). Autism traits: the importance of comorbid problems for impairment and contact with services. Data from the Bergen Child Study. Research in Developmental Disabilities http://dx.doi.org/10.1016/j.ridd.2016.01.002 in press.

Schetter DC, Tanner L (2012). Anxiety, Depression and Stess in Pregnancy: Implications for Mothers, Children, Research, and Practice. Behavioural Medicine, 2: 25-28.

Seymour M, Wood C, Giallo R, Jellett R (2013). Fatigue, Stress and Coping in Mothers of Children with an Autism Spectrum Disorder. Journal of Autism and Developmental Disorders, 43: 
Journal of Maternal and Child Health (2018), 3(4): 278-286

https://doi.org/10.26911/thejmch.2018.03.04.05

1547-1554. doi:10.1007/s10803-0121701-y.

Soetjiningsih, Ranuh Gde (2013). Buku Tumbuh Kembang Anak Edisi 2, Jakarta: Penerbit Buku Kedokteran EGC.

Taylor LE, Swerdfeger AL, Eslick GD (2014). Vaccines are not Associated with Autism: An Evidence-Based Meta-Analysis of Case-Control and Cohort Studies. Vaccine, 32: 3623-

3629. doi:10.1016/j.vaccine.2014.04.085 .

Zerbo O, Iosif AM, Walker C, Ozonoff S, Hansen RL, Hertz-Picciotto I (2013). Is Maternal Influenza or Fever during Pregnancy Associated with Autism or Developmental Delays? Results from the CHARGE (childhood Autism Risks from Genetics and Environment) Study. Journal of Autism and Developmental Disorders, 43: 25-33. doi:10.1007/s10803-012-1540-X. 